\title{
Proposed changes to NHS legislation
}

\author{
(c) $(\mathbb{0} \Theta$ OPEN ACCESS \\ Workarounds that need greater clarity
}

\author{
Hugh Alderwick assistant director, Tim Gardner senior policy fellow, Ruth Thorlby assistant director, \\ Jennifer Dixon chief executive
}

Health Foundation, London, UK

In the midst of political chaos over Brexit, national NHS bodies have asked the government to consider changing NHS

legislation. ${ }^{1}$ The changes are designed to make it easier for the NHS to deliver its long term plan, which focused on integrating services, boosting prevention, and improving care quality. ${ }^{2} \mathrm{NHS}$ England is consulting on the proposals and the parliamentary health and social care select committee is currently examining them. ${ }^{3}$

Why do NHS leaders think new laws are needed? The answer lies in the legacy of the last round of legislative changes in the NHS and shifting directions in health policy.

The Health and Social Care Act 2012 sought to strengthen the role of competition in the health system and introduced changes to the NHS's structure. These included abolishing some organisations (such as strategic health authorities) and creating new ones (such as clinical commissioning groups (CCGs)). Fast forward to 2019, however, and competition rarely gets a mention in NHS policy. Instead, the long term plan-like the five year forward view before it ${ }^{4}$ - calls for collaboration to improve care and manage resources. This is in recognition of the need to join up services for people with multiple health needs.

Despite having no place in the structure created by the 2012 act, sustainability and transformation partnerships and integrated care systems-partnerships of NHS commissioners, providers, and local government-have been created by NHS England to lead local improvements.

The result is a growing gap between the legal framework for the NHS and the reality of how the system is managed. This has created tensions for NHS organisations stuck in the middle-for example, CCGs seeking to navigate rules on competitive tendering while coordinating local services. The proposed legislative changes are therefore designed to bring the formal rules governing the NHS closer in line with the direction the system is taking.

\section{Lack of clarity}

The proposals are simultaneously important and underwhelming. On the one hand, the changes would dilute the split between
NHS commissioners and providers that has existed since 1991. New committees could be established spanning clinical commissioning groups, hospitals, and other providers, with mechanisms for constituent organisations to delegate decisions to them. Detail is lacking, but the idea is that the new committees would make collective decisions on local priorities and spending. Clinicians from local hospitals would be able to join GPs on the governing bodies of CCGs (even if the CCG commissions services from their organisation). And commissioners and providers could make joint appointments more freely.

On the other hand, no new types of statutory bodies-for example, sustainability and transformation partnerships or integrated care systems-would be created under the proposals. This avoids structural upheaval but could leave local accountabilities murky. It would remain hard to say who is in charge. And commissioners and providers would still face potentially conflicting requirements to plan services jointly but commission them separately. In this sense, the proposals risk replacing one set of workarounds with another.

Several changes could make the system simpler to manage. New joint commissioning rules-for example, making it easier for neighbouring commissioning groups to make joint decisions in commissioning primary care-could help reduce fragmentation experienced in the current system. ${ }^{5}$ A new "best value" test is suggested to guide NHS commissioners in deciding whether to award contracts directly to NHS providers or competitively tender-potentially reducing transaction costs and making it easier for commissioners to work with providers to coordinate services. But what this would look like in practice is not set out. Existing tendering rules are confusing. ${ }^{6}$ Any new system must provide greater clarity.

Potential benefits of other changes are less obvious. The proposals would simplify the process for agreeing mergers involving NHS foundation trusts (removing the role of the Competition and Markets Authority). But evidence on the effect of NHS hospital mergers on cost and quality is mixed..$^{78} \mathrm{New}$ NHS integrated care providers, able to hold single contracts for all NHS services in a given area, are also proposed. Integrating 
care can bring benefits to patients. ${ }^{9}$ But integrating organisations and contracts does not necessarily lead to more integrated care. ${ }^{10}$ Both changes may also reduce the range of local providers that patients can choose for treatment.

Policy makers must ask themselves whether changes to legislation-however logical from a technical perspective-will bring additional costs, upheaval, and unintended consequences. The 2012 act was damaging and distracting. ${ }^{11}{ }^{12}$ The risk is that time and resources are wasted again. Other policy priorities, such as filling the NHS's staffing gaps, may be more important. ${ }^{13}$ As consultation on the proposals continues, NHS leaders should articulate a clearer narrative for the changes, how they fit within the longer term direction for the NHS, and the logic for how the system will improve as a result. Competition is out; collaboration is in. But what other policies will be used to support improvements? Will more legislation be needed later to formally create integrated care systems? And-most importantly - what will be the benefits for patients, and how will they be assessed? Without answers to these questions, the new proposals risk looking like workarounds without a clear route map.

Competing interests: We have read and understood BMJ policy on declaration of interests and have no relevant interests to declare.

Provenance and peer review: Commissioned; not externally peer reviewed.

1 NHS England, NHS Improvement. Implementing the NHS long term plan: proposals for possible changes to legislation. 2019. https://www.longtermplan.nhs.uk/publication/ implementing-the-nhs-long-term-plan/
2 NHS. The NHS long term plan. 2019. https://www.longtermplan.nhs.uk/

3 Health and Social Care Committee. NHS long-term plan: legislative proposals inquiry. https://www.parliament.uk/business/committees/committees-a-z/commons-select/healthand-social-care-committee/inquiries/parliament-2017/nhs-legislation-inquiry-17-19/ 4 NHS England. Five year forward view. 2014. https://www.england.nhs.uk/wp-content/ uploads/2014/10/5yfv-web.pdf

5 Checkland K, Hammond J, Sutton M, et al. Understanding the new commissioning system in England: contexts, mechanisms and outcomes. 2018. http://blogs.lshtm.ac.uk/prucomm/ files/2018/11/Understanding-the-new-commissioning-system-in-England-FINAL-REPORTPR-R6-1113-25001-post-peer-review-v2.pdf

6 Allen $\mathrm{P}$, Osipovič $\mathrm{D}$, Shepherd E, etal . Commissioning through competition and cooperation in the English NHS under the Health and Social Care Act 2012: evidence from a qualitative study of four clinical commissioning groups. BMJ Open 2017;7:e011745. 10.1136/bmjopen-2016-011745 28183806

7 Gaynor M, Laudicella M, Propper C. Can governments do it better? Merger mania and hospital outcomes in the English NHS. Centre for Market and Public Organisation, University of Bristol, 2012.

8 Collins B. Foundation trust and NHS trust mergers: 2010 to 2015. King's Fund, 2015.

9 Baxter S, Johnson M, Chambers D, Sutton A, Goyder E, Booth A. Understanding new models of integrated care in developed countries: a systematic review. Health Services and Delivery Research 2018;6. 10.3310/hsdr06290 30148581

10 Alderwick H, Shortell SM, Briggs ADM, Fisher ES. Can accountable care organisations really improve the English NHS? Lessons from the United States. BMJ 2018;360:k921. 10.1136/bmj.k921 29500301

11 Ham C, Baird B, Gregory S, Jabbal J, Alderwick H. The NHS under the coalition government. Part one: NHS reform. King's Fund, 2015.

12 Timmins N. Never again? The story of the health and social care act 2012: a study in coalition government and policy making. The King's Fund, Institute for Government, 2012

13 Beech J, Bottery S, Charlesworth A, etal . Closing the gap: key areas for action on the health and care workforce. Health Foundation, 2019.

Published by the BMJ Publishing Group Limited. For permission to use (where not already granted under a licence) please go to http://group.bmj.com/group/rights-licensing/ permissionsThis is an Open Access article distributed in accordance with the Creative Commons Attribution Non Commercial (CC BY-NC 4.0) license, which permits others to distribute, remix, adapt, build upon this work non-commercially, and license their derivative works on different terms, provided the original work is properly cited and the use is non-commercial. See: http://creativecommons.org/licenses/by-nc/4.0/. 